Trakya Eğitim Dergisi

Cilt 10, Sayı 1

Ocak 2020, 76-91

Geliş Tarihi: 28.02.2019

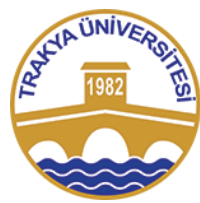

ISSN: 2630-6301
Trakya Journal of Education

Volume 10, Issue 1

January 2020, 76-91.

Doi: $10.24315 /$ tred.533849

Araştırma Makalesi)

Research Article

\title{
Öğretmen Adaylarının Kimya Alanında Çalışan Bilim İnsanı İmajları ve Bu İmajları Etkileyen Faktörler ${ }^{1}$,
}

\section{Images of The Pre-Service Teachers About The Scientists Working in The Field of Chemistry and Factors Affecting These Images}

\section{Volkan BİLİR ${ }^{2}$, Gülseda EYCEYURT TÜRK ${ }^{3}$, Ümmiye Nur TÜZÜN ${ }^{4}$}

ÖZ: Bu araştırmanın amacı öğretmen adaylarının kimya alanında çalışan bilim insanı imajlarını ve bu imajları etkileyen faktörleri araştırmaktır. Bu amaçla araştırma İç Anadolu Bölgesi'nde bir devlet üniversitesinde 2017-2018 eğitim-öğretim y1lı içerisinde yapılmıştır. Araştırma, resim iş, fen bilgisi, ilköğretim matematik, sosyal bilgiler ve rehberlik ve psikolojik danışmanlık anabilim dallarında karma yöntem temelinde yürütülmüştür. Araştırmaya üçüncü ve dördüncü sinıftan toplam 271 öğretmen aday1 katılmıștır. Araştırmada öğretmen adaylarının kimya alanında çalışan bilim insanı hakkındaki zihinsel resimlerini belirleyebilmek amacıyla, Bilim İnsanı Çiz (DAST) testi kullanılmıştır. Öğretmen adaylarından kimya alanında çalışan bilim insanının nasıl çalıştığını, bu bilim insanının neler yaptığını düşünerek, bu düşünmelerini mümkün olduğunca detaylandırarak çizmeleri istenmiştir. Öğretmen adaylarının çizimlerinin analizinde iki farklı Bilim İnsanı Çizim Kontrol Listesi kullanılmıştır. Öğretmen adaylarının çizimlerinde yer almayan ancak çizimlerinin açıklamalarından elde edilen nitel verilerin çözümlenmesi içerik analizi yoluyla yapılmıştır. Analiz sonuçlarından öğretmen adaylarının kimya alanında çalışan bilim insanı imajlarının geleneksel bilim insanı algısı ile örtüştüğü görülmüştür. Ayrıca sosyal bilgiler öğretmen adaylarının kimya alanında çalışan bilim insanı imajlarının istatistiksel olarak diğer bölüm öğretmen adaylarından anlamlı derecede farklılık gösterdiği sonucuna ulaşılmıştır.

Anahtar sözcükler: Bilim, bilimin doğası algısı, bilim insan imaj1, kimya eğitimi

\begin{abstract}
The aim of this research is to investigate the science images of pre-service science teachers and the factors affecting these images. For this purpose, the research was conducted in a public university in the Central Anatolia Region in the 2017-2018 academic year. The research was carried out on the basis of a mixed method in the fields of painting, science, elementary mathematics, social studies and guidance and psychological counseling. A total of 271 pre-service teachers from the third and fourth class participated in the study. In order to determine the mental images of the preservice science teachers about the scientists working in the field of chemistry, Draw a Scientists Test (DAST) test was used. Pre-service who were working in the field of chemistry were asked to think about how the scientists worked and what they were doing and to draw them as detailed as possible. Two different Scientist Drawing Control Lists were used in the analysis of pre-service teachers' drawings. The analysis of the qualitative data obtained from the explanations of the drawings, which are not included in the drawings of the pre-service teachers, were made through content analysis. From the results of the analysis, it was seen that the science preservice working in the field of chemistry matched the perception of traditional scientists. In addition, it has been concluded that social studies pre-service teacher differ significantly from other preservice teacher in the field of chemistry.
\end{abstract}

Keywords: Science, how science works, scientist image, chemistry education

\section{Cite this article as:}

Bilir, V., Eyceyurt Türk, G. \& Tüzün, Ü. N. (2020). Images of the pre-service teachers about the scientists working in the field of chemistry and factors affecting these images. Trakya Eğitim Dergisi, 10(1), 76-91.

\section{Introduction}

\section{EXTENDED ABSTRACT}

As educators if we want our students to learn properly how science works, then first we must educate the pre-service teachers from all fields in order to make them construct a scientifically true nature of science perception. In literature, there are studies investigating not only the pre-service

${ }^{1}$ Bu çalıșmanın bir kısmı I. Uluslararası Güzel Sanatlar ve Eğitimi Kongresi’nde (28-30 Nisan 2018) sözlü bildiri olarak sunulmuștur. ${ }^{2}$ Dr. Öğr. Üyesi, Düzce Üniversitesi, Eğitim Fakültesi, Fen Bilgisi Eüğitimi Anabilim Dalı, e-posta: volkanbilir@duzce.edu.tr, ORCID: 0000-0002-8709-6257

${ }^{3}$ Dr. Öğr. Üyesi, Sivas Cumhuriyet Üniversitesi, Eğitim Fakültesi, Kimya Eğitimi Anabilim Dalı, e-posta: geyceyurt@ cumhuriyet.edu.tr, ORCID: 0000-0002-4757-3696

${ }^{4}$ Milli Eğitim Bakanlığı, e-posta: u_tuzun@hotmail.com, ORCID: 0000-0001-9114-0460 
teachers' perception of scientists and how science works, but also the educations making them gain a proper nature of science perception. Mbajiorgu and Iloputaife (2001) had studied throughout 14 weeks for making teachers gain a proper image of science on the basis of a constructivist teaching. At the end of the research, it was found that the education made the teachers construct more proper mental models about scientists. In another research, it was emphasized the significance of the activities making preservice teachers construct a proper nature of science perception (Demirbas, 2009). Dogan et al. (2014) showed that in-service trainings could also improve teachers' nature of science perception. Koseoglu, Tumay and Ustun (2010) utilized a teaching package for improving pre-service teachers' nature of science perception. They determined that the pre-service teachers would gain a persistent nature of science perception, if only the education lasts long.

So in this research, pre-service teachers' images of scientists studying in the field of chemistry and the factors affecting these images would be investigated. The research questions were as following:

1. Do the pre-service teachers' images of scientists studying in the field of chemistry differ according to gender?

2. Do the pre-service teachers' images of scientists studying in the field of chemistry differ according to departments they are educating in?

3. Do the pre-service teachers' images of scientists studying in the field of chemistry differ according to the classes they are educating in?

This research differed from the literature because it would investigate the pre-service teachers' images of scientists studying in the field of chemistry and also it would be studied in detail for detecting these images by the help of two parallel scales.

\section{Method}

Mixed method means using quantitative and qualitative data together for making much more plausible conclusions in the field of social sciences (Creswell, 2017, p. 2). So in this research a mixed method was utilized for determining pre-service teachers' images of scientists studying in the field of chemistry and the factors affecting these images. The participants of this research were 271 pre-service teachers educating at a university in Turkey in 2017-2018 academic year.

In the application process of the research first the pre-service teachers were asked to draw scientist and then to explain their drawings. For analyzing the participants' drawings, two different scales' coding was utilized. First scale was Draw A Scientist Checklist: DAST-C, was developed by Finson, Beaver \& Cramond (1995). DAST-C consisted of 15 items representing the traditional scientists' characteristics. When coding each of the items, if the characteristic of this item occurred in this drawing, 1 was given, otherwise 0 was given.

The other scale was Ruiz-Mallen ve Escales' (RME-C) (2012). RME-C consisted of 14 items representing the traditional scientists' characteristics but this time different form the former's. When coding each of the items, if the characteristics of this item occurred int the drawing, 1 was given, otherwise 0 was given.

Quantitative and qualitative analysis techniques were utilized for the gathered data. In the research for testing the consistency, 27 (1/10 of the participants) participants' drawings were selected randomly. And then three independent researchers coded each of the items according to DAST-C and RME-C. Statistical cappa value was 0,928 for DAST-C and 0,934 for RME-C.

\section{Findings, Result and Discussion}

At the end of the research, it was found that the pre-service teachers' images of scientists studying in the field of chemistry were alike the traditional ones. The social sciences' students' scientist images differed statistically meaningful from the other departments.

The extra data gathered from the pre-service teachers' drawings and explanations were analyzed by content analysis and it showed that the drawings were a like the famous scientists such as Einstein, Kohler and Walter White because media culture affected these drawings.

If we want our students to construct scientifically true images about how science works, first we must educate our pre-service teachers properly on the basis of truly constructed mental models in the subject of nature of science. As a suggestion of the study, the research could be conducted with a much bigger group. And also the pictures in the books about scientists must reflect the scientifically true constructed nature of science. 


\section{GíRIŞ}

Yirminci yüzyılın ilk yarısında, bilim tarihçileri ve epistemologların çalışmalarıyla bilimsel bilginin doğasıyla ilgili fikirler büyük oranda değişmiştir. Bu şekilde bilim, bir insan aktivitesi olarak dikkate alınmaktadır (Gürses, Doğar ve Yalçın, 2005). Bilimsel bilginin öne çıkan özelliklerinden; değişebilir olması, olgusal ve öznel olması, çıkarım, hayal gücü ve yaratıcılık içermesi, sosyal ve kültürel olarak yapılandırılması, gözlem ve çıkarımın farklı kavramlar olması, teorinin gelişerek kanuna dönüştürülemeyeceği boyutları temelinde özetlenmesi bilim literatüründe doğru bir bilimin doğası algısı olarak öne çıkmaktadır (Abd-El-Khalick, Bell ve Lederman, 1998).

Pek çok ülkede öğretim programlarının önemli bileşenlerinden biri, doğru bir bilimin doğası algısına sahip bilim okuryazarı bireyler yetiştirmektir. Köseoğlu, Tümay ve Budak (2008) son yıllarda bilim ve bilimin doğası ile ilgili paradigmal değişimlerin yaşandığını ve birçok araştırmada öğrenci ve öğretmenlerin doğru bir bilimin doğası algısı edinmesine odaklanıldığını ifade etmişlerdir.

Öğrencilere doğru bir bilimin doğası algısı edindirecek öğretim ortamlarının yapılandırılmas1 ancak öğretmenlerin doğru bir bilimin doğası algısına sahip olmaları ile mümkündür (Doğan, Çakıroğlu, Bilican ve Çavuş- Güngören, 2014). Ancak yapılan bazı araştırmalar fen öğretmenlerinin bilimin doğası ile ilgili bazı yanlış görüşlere; bilimin doğası mitlerine sahip olduğunu göstermektedir (Köseoğlu, Tümay ve Üstün, 2010). Bireylerde bilimin doğas1 algısı ile bilimin doğası mitlerinin örtüşmemesi, bireylerde istenmeyen bilgi türleri olarak ortaya çıkar.

Literatürde öğretmen adaylarının bilim insanı imajını ve bilimin doğası algısını araştıran araştırmalar ile öğretmen adaylarına sunulan eğitimlerle daha doğru bilimin doğası algısına sahip olmalarını sağlamaya yönelik araştırmalar da mevcuttur. Mbajırgu ve Iloputaife (2001) araştırmalarında 26 ögretmen adayı ile 14 haftalık bir süreçte yapılandırmacı yaklaşım temelinde, öğretmenlerin bilim insanı algısını geliştirmek amaçlı çalışmışlardır. Ön test, son test uygulamalardan ve ayrıca yedi öğretmen adayı ile derinlemesine görüşmelerden elde edilen bulgular ışı̆̆ında, araştırma sürecinde verilen eğitimin öğretmen adaylarının bilimsel olarak daha doğru bir bilim insanı algısı edinmelerini sağladıklarını öne sürmüşlerdir. Demirbaş’a (2009) göre öğretmenlerin doğru bir bilimin doğası algısı edinebilmeleri için bilim insanının çalışma biçimleriyle örtüşen etkinliklerin bilimsel metotlar ile uygulanması gereklidir. Köseoğlu, Tümay ve Üstün'e (2010) göre ise öğretmen adaylarının bilimin doğası algılarını geliştirmek için bilimin doğası öğretimi gelişim paketi uygulanmıştır, bu uygulama sonucunda kalıcı ve doğru bir bilimin doğası algısı oluşumu için uzun bir sürece ihtiyaç olduğu vurgulanmıştır

Bireylerin yaşantıları ile kazandıkları bilim algısı ve bu bilim algısındaki önemli unsurlardan biri olan bilim insanı imajı araştırmacılar tarafından önemli bir başlık haline gelmiştir. Bireylerin zihinlerinde bilim insanına ilişkin doğru bir imaja sahip olmak için ise başlıca koşul bilimin doğasını anlamak olarak karşımıza çıkmaktadır (Kaya, Doğan ve Öcal, 2008). Öğrencilerde oluşan bilim insanı imajı, bilime ve bilim insanlarına bakış açılarını etkilemektedir. Bilim insanlarına yönelik olumsuz veya yanlış düşünceler öğrencileri, bilim insanlarından ve bilimden uzaklaştırmaktadır. Öğrencilerin bilim insanı imajını etkileyen birçok değişken söz konusudur. Medya, aile, akran, ders kitapları ve öğretmenler öğrencilerdeki bilim insanı imajını oluşturmada etkili olmaktadır (Schibeci ve Sorenson 1983, Tenenbaum ve Leaper, 2003; Scott ve Mallinckrodt, 2005;Türkmen, 2008). Literatürde öğretmen adaylarının bilim insanı resmetme vasıtasıyla bilimin doğasına dair algılarını araştıran bir çalışmada, öğretmen adaylarının bilimin doğasına dair algılarının öğrencilerinkine benzediği; zihinlerinde geleneksel bir bilim insanı imajının olduğu vurgulanmıştır. Çalışma bunun sebebini öğretmen adaylarının lise öğrencilikleri sırasında deneyimlerinden edindikleri ve sürdürdükleri yanlış imajlar olarak ortaya koymuştur (Rahm ve Charbonneau, 1997). Koren ve Bar (2009) farklı kültürlerdeki öğretmen adaylarının bilim insanı algısını karşılaştırmalı olarak çalıştıkları araştırmalarında, öğretmen adaylarının daha geleneksel bilim insanı imajına sahip olduklarını öne sürerken, Ağgül-Yalçın (2012) öğretmen adaylarının bilim insanını erkek, 30-50 yaşında, laboratuvarda çalışan, deney yapan ve düşünen kişiler olarak betimlediklerini belirtmiş̧tir. Benzer biçimde bir başka araştırmada da öğretmen adaylarının zihinlerindeki bilim insanı resimlerinin, gözlüklü, laboratuvar önlüklü, dağınık saçlı, kısa boylu ve yaşlı erkek olduğu ortaya konmuştur (Çermik, 2013). Ayrıca bilim insanlarının meraklı, araştırmacı, sabırlı, eleştirel, kararlı, mantıklı ancak asosyal olmaları söz konusudur. Şenel ve Aslan 
(2014) araştırmalarında öğretmen adaylarının bilim ve bilim insanına dair çocuk, 1şık, güneş gibi gerçekçi olmayan algılara sahip olduklarını ortaya koyarken, Gürses, Doğar ve Yalçın (2005) ise öğretmen adaylarının teorinin değişebilir, kanunun ise değişemez olduğu bilimin doğası mitine, yanlış algısına sahip olduklarının altını çizmişlerdir. Fen bilgisi öğretmen adayları ve din kültürü ve ahlak bilgisi öğretmen adayları ile yapılan bir çalışmada fen bilgisi öğretmen adaylarının bilim insanı imajlarında çalışma alanı olarak daha çok kapalı alanları ve gizemli yerleri tercih ettikleri gözlenirken, din kültürü ve ahlak bilgisi öğretmen adaylarının bilim insanı imajlarında çalışma alanı olarak daha çok çalışma odas1 ve kütüphaneye yer verdikleri görülmüştür (Ağgül-Yalçın, 2012). Öğretmen adaylarını ile yapılan başka bir araştırmada, öğretmen adaylarının bilimin tanımı, bilimsel bilginin değişkenliği, önerme, kuram ve kanunların yapısı, bilimsel yöntem ve gözlemin doğası ile ilgili yetersiz ve yanlış görüşlere sahip olduğu şeklinde sonuca ulaşılmıştır (Aslan, Yalçın ve Taşar, 2009).

Özkan, Özeke, Güler ve Şenocak (2017) üniversite öğrencilerinin bilim insanı imajı üzerine yapmış olduğu çalışmada, üniversite öğrencilerinin; karmaşık yüz tüyleri olan, erkek, orta yaşlı veya yaşlı, laboratuvar gibi iç mekânlarda fizik, kimya, biyoloji, matematik gibi sayısal alanlarda çalışan bilim insanı geleneksel bilim insanı imajı sergiledikleri sonucuna ulaşılmıştır. Üstün zekalılar öğretmenliği bölümü öğrencileri ile bilim insanı imajlarına yönelik yapılan başka bir araştırmada, bilim insanlarının genellikle gözlüklü, laboratuvar önlüğü giymiş, iç ortamda deney tüpleri, beherler ile çalışan, kitap ve teknoloji ürünleri kullanan ve baskın olarak yalnız olarak çalışan erkekler olduğu sonucu ortaya çıkmıştır (Camcı-Erdoğan, 2018). Ürey, Karaçöp, Göksu ve Çolak (2017) tarafından yapılan öğretmen adaylarının bilim insanlarına yönelik çalışmada ise fen bilimleri kökenli öğretmen adaylarının bilim insanını, marjinal görünümlü, dağınık, önlük giyinen, deney yapan, icat yapan, problemlere çözüm üreten, çalışma ortamı olarak laboratuarı ve laboratuardaki malzemeleri kullanan bireyler olarak algıladıkları görülürken; sosyal bilimler kökenli öğretmen adaylarının bilim insanını, klasik görünümlü, düzenli, evrensel ve çok yönlü düşünen, çalışma ortamı olarak kütüphane ve çalışma odasını kullanan bireyler olarak algıladıkları sonucunu ortaya koymuşlardır.

Bilim insanı imajlarının belirlenmeye çalışıldığı araştırmalarda veri toplama aracı olarak genellikle Chambers (1983) tarafından geliştirilen Bir Bilim İnsanı Çiz Testi (Draw A Scientest TestDAST) kullanılmaktadır (Bodzin ve Gehringer, 2001; Jones ve Bangert, 2006; Akçay, 2011; Milford ve Tippet, 2013; Acisli ve Kumandas, 2019; Gheith ve Aljaberi, 2019; Meyer, Guenther ve Joubert, 2019). Bu veri toplama aracından elde edilen veriler analizinde bazı araştırmalarda Finson, Beaver ve Cramond (1995) tarafından geliştirile Bilim İnsanı Çizim Kontrol Listesi (Draw A Scientist Checklist: DAST-C) kullanılırken (Fung, 2002; Subramaniam, Harrell ve Wojnowski, 2013; Karaçam, 2016; Camc1-Erdoğan, 2018; Emvalotis ve Koutsianou, 2018; Dede, 2019), Özkan vd., (2017) çalışmalarında DAST-C ile birlikte Ruiz-Mallen ve Escales (2012) tarafından geliştirilen kodlama cetveli (RME-C)' kullanılmışlardır.

Dünyamız için son derece önemli bir bilim dalı olan kimya hem doğal hem de sosyal alanlarda ve gelişimini aktif olarak devam ettirmektedir (Aydın, 2016). Son derece önemli olan bu bilim dalında çalışan bu bilim insanlarına yönelik öğretmen adaylarının imajları ve bu imajları etkileyen faktörler aşağıdaki sorular ile bu çalışmada araştırılması amaçlanmıştır.

1. Öğretmen adaylarının kimya alanında çalışan bilim insanı imajları cinsiyetlere göre istatistiksel olarak anlamlı farkl1l1k göstermekte midir?

2. Öğretmen adaylarının kimya alanında çalışan bilim insanı imajları öğrenim gördükleri sınıf düzeylerine istatistiksel olarak anlamlı farkl11ık göstermekte midir?

3. Öğretmen adaylarının kimya alanında çalışan bilim insanı imajları öğrenim gördükleri bölümlere göre istatistiksel olarak anlamlı farklılık göstermekte midir?

$\mathrm{Bu}$ araştırmanın farklı bölümlerde öğrenim gören öğretmen adaylarının sahip oldukları kimya alanında çalışan bilim insanı imajlarının ortaya konmasında karşılaşsırmalı ikili skala kullanımı ile daha ayrıntılı ve daha güvenilir sonuç sunması yönüyle literatüre katkı sağlayacağı düşünülmektedir.

\section{YÖNTEM}

$\mathrm{Bu}$ araştırmada da öğretmen adaylarının kimya alanında çalışan bilim insanı imajlarını betimlemek amacıyla hem nicel veriler, hem nitel veriler toplanmış, iki veri seti bütünleştirilerek sonuçlar çıkarılmıştır. Araştırmada karma yöntem kullanılmıştır. Karma yöntem, araştırmacıların, 
araştırmanın amacına yönelik ortaya koydukları problemleri anlamak için hem nicel veriler, hem de nitel veriler topladığı, iki veri setini birbiriyle bütünleştirdiği ve daha sonra bu iki veri setini bütünleştirmenin avantajlarını kullanarak sonuçlar çıkardığı, sağlık, sosyal ve davranış bilimleri alanında kullanılan bir araştırma yaklaşımıdır (Creswell, 2017).

\section{Evren ve Örneklem}

Türkiye'nin İç Anadolu Bölgesinde yer alan bir devlet üniversitesinin eğitim fakültesinin beş farklı anabilim dalının üçüncü ve dördüncü sınıflarında öğrenim gören toplam 271 öğretmen adayı araştırmanın örneklemini oluşturmuştur. Araştırmanın örneklemini belirlemede, örnekleme yöntemlerinden biri olan uygun örnekleme yöntemi kullanılmıştır. Bu yöntem ile eğitim fakültesinin beş farklı anabilim dalında öğrenim gören öğretmen adaylarına ulaşılmıştır. Üniversite kültürüne sahip olmaları, çeşitli alanlarda çalışan bilim insanları ile çalışmış olmaları ve onlarla iletişim içerisinde olmaları sebebi ile üçüncü ve dördüncü sınıf öğrencileri örneklem olarak seçilmiştir. www.raosoft.com/samplesize.html internet sitesinden örneklem büyüklügünü hesaplamada faydalanılmıştır. Hesaplama sonucunda araştırmanın \%90 güven aralığında ulaşması gereken kişi sayısı 250 katılımcı olarak hesaplanmıştır. Tablo 1'de örneklemin bazı demografik özellikleri sunulmuştur.

Tablo 1. Öğretmen adaylarının bölüm, sınıf ve cinsiyete göre dağılımı

\begin{tabular}{|c|c|c|c|}
\hline \multicolumn{2}{|c|}{ Demografik özellikler } & \multirow{2}{*}{$\begin{array}{l}\mathbf{f} \\
29\end{array}$} & \multirow{2}{*}{$\begin{array}{l}\% \\
10,7\end{array}$} \\
\hline Bölüm & Resim Öğretmenliği & & \\
\hline & $\begin{array}{l}\text { İlköğretim } \quad \text { Matematik } \\
\text { Öğretmenliği }\end{array}$ & 44 & 16,2 \\
\hline & $\begin{array}{l}\text { Psikolojik Danışmanlık ve } \\
\text { Rehberlik Öğretmenliği }\end{array}$ & 53 & 19.6 \\
\hline & Sosyal Bilgiler Öğretmenliği & 61 & 22,5 \\
\hline & Fen Bilgisi Öğretmenliği & 84 & 31 \\
\hline \multirow[t]{2}{*}{ Sinıf } & 3. Sinif & 162 & 59,8 \\
\hline & 4. Sinif & 109 & 40,2 \\
\hline \multirow[t]{2}{*}{ Cinsiyet } & Kadın & 184 & 67.9 \\
\hline & Erkek & 87 & 32,1 \\
\hline
\end{tabular}

\section{Veri Toplama Araçları}

Chambers tarafından geliştirilen 'Bilim İnsanı Çiz Testi (DAST) araştırmada veri toplama aracı olarak kullanılmıştır (Chambers, 1983). Geliştirilen bu test ile araştırmalarda araştırmaya katılan kişilerin zihinlerinde yer alan bilim insanına yönelik imajlarını resim çizerek ortaya çıkarmalarına olanak sağlanmaktadır. Katılımcılar DAST ile boş bir kâğıda bilim insanı ile ilgili fikirlerini resmederler. DAST'ın diğer veri toplama araçlarına göre avantajları vardır. Bu avantajları; okuma veya yazmaya gerek duyulmaması, katılımcıların kendi düşüncelerini özgürce yansıtabilmesi, uygulanmasının kolay olması şeklinde sıralayabiliriz (Öcal, 2007).

Araştırmaya katılan öğretmen adaylarının çizimlerinin analizinde iki farklı Bilim İnsanı Çizim Kontrol Listesi kullanılmıştır. Bunlar ilki Finson vd., (1995) tarafından geliştirilen, 15 farklı bağımsız değişkenden oluşan kodlama cetveli (Draw A Scientist Checklist: DAST-C)'dir. İkincisi ise RuizMallen ve Escales (2012) tarafından geliştirilen 14 bağımsız değişkenden oluşan kodlama cetveli (RME-C)'dir.

Kullanılan Bilim İnsanı Çizim Kontrol Listelerinde, geleneksel bilim insanını yansıtan özelliklerin varlığında 1 , olmaması durumunda ise 0 puan verilerek yapılmıştır. 
Araştırmada verileri daha da detaylandırmak amacıyla iki farklı Bilim İnsanı Çizim Kontrol Listesi kullanılmıştır. DAST-C ve RME-C'de birç̧ok ortak değişkenin olduğu gibi ikisinin de birbirinden farklı değişkenleri de bulunmaktadır. Örneğin RME-C de bilgi sembolleri, köken, tehlike işaretleri, düşünce bulutu ve gizlilik belirtileri gibi boyutlar yer almazken DAST-C de yer almaktadır. Diğer taraftan, bilim insanı kişiliği, yalnız veya ekiple çalışma, araştırma disiplini ve çalışma şekli değişkenler RME-C de yer alırken DAST-C de yer almamaktadır. Bu şekilde öğretmen adaylarının çizimleri daha detaylı incelenmiştir

\section{Veri Toplama Süreci}

Çalışmaya öğretmen adaylarının katılıp katılmamak istediği sorulmuş ve çalışmaya katılmak isteyen öğretmen adaylarına DAST sunularak, kimya alanında çalışan bilim insanını düşünmelerini, kimya alanında çalışan bilim insanının nasıl çalıştığını ve neler yaptığını zihinlerinde canlandırmaları istenmiş ve zihinlerinde oluşan imajları detaylı bir şekilde verilen çalışma yaprağına çizmeleri istenmiştir. Ayrıca öğretmen adaylarına, "Çizdiğiniz kimya alanında çalışan bilim insanı bilimsel bilgiye nasıl ulaşıyor, nasıl bilim yapıyor?" sorusu da yöneltilmiştir. Bu soru ile çalışmaya katılan öğretmen adaylarından, çizimlerine ek olarak yazılı şekilde de bilgi almak amaçlanmıştır.

\section{Verilerin Analizi}

Öğretmen adaylarının kimya alanında bilim insanına yönelik imajları iki farklı Bilim İnsanı Çizim Kontrol Listesinden elde edilen verilerin analizinden elde edilmiştir. Her öğretmen adayının alabileceği puan, DAST-C'den 0-15 puan aralığında, RME-C'den 0-14 puan aralığında değişmektedir. Araştırma verileri SPSS istatistik programı kullanılarak analiz edilmiştir. Analiz öncesinde, dağılımların normal dağılım gösterip göstermediğinin belirlenmesi için Kolmogorov-Smirnov normallik testi uygulanmıștır. Kolmogorov-Smirnov testi sonucunda tüm dağılımların her iki kontrol listesinde tüm gruplarda normal dağ 1 lım gösterdiği belirlenmiştir. Böylece öğretmen adaylarının zihinlerinde yer alan kimya alanında çalışan bilim insanı imajlarının cinsiyete gore farklılaşıp farklılaşmadı̆̆ını bağımsız gruplar t-testi, kimya alanında çalışan bilim insanı imajlarınının hangi bölümler arasında anlamlı oalrak farklılaştığının tespiti için scheffe testi ile kullanılmıştır.

Öğretmen adaylarının çizimlerinin analizinin son aşamasında ise iki farklı Bilim İnsanı Çizim Kontrol Listesinde yer almayan ancak öğretmen adaylarının çizimleri ve bu çizimlerin olduğu çalışma yaprağında yer alan açı uçlu soruya yazılan ifadeler ile toplanan veriler içerik analiziyle çözümlenmiştir. Araştırmada iki farklı Bilim İnsanı Çizim Kontrol Listesinde kodlama yapan araştırmacılar arası puanlama tutarlılığı test etmek için ise rastgele seçilen 27 öğretmen adayının çizimi seçilmiştir. Seçilen çizimler farklı üç ayrı alan uzmanı tarafından iki farklı Bilim İnsanı Çizim Kontrol Listesine göre kodlamalar yapılmış ve yapılan kodlamalar kappa istatistiği ile araştırmacılar arası uyuma bakılmıştır. Buna göre, DAST-C için kappa istatistiği değeri 0,928 RME-C için ise 0,934 olarak hesaplanmıştır. Bu değerler kodlayıcılar arasındaki tutarlılığını yüksek olduğunu göstermektedir.

\section{BULGULAR}

Bu bölümde kimya alanında çalışan bilim insanına dair imajlarını belirleyeceğimiz öğretmen adaylarının; cinsiyetlerine, öğrenim gördükleri sınıf düzeylerine ve öğrenim gördükleri bölümlere göre istatistiksel olarak anlamlı bir şekilde farklılaşıp farklılaşmadığını tespit etmek amacıyla yapılan analiz sonuçları sunulmuştur.

Öğretmen adaylarının DAST-C bilim insanı kontrol listesindeki bağımsız değişkenlere göre aldıkları ortalama puanın 15 üzerinden 6.26, RME-C bilim insanı kontrol listesindeki bağımsız değişkenlere göre 14 üzerinden 8.26 olarak bulunmuştur.

Araştırma sorularına cevap aramak üzere araştırmaya katılan öğretmen adaylarının kimya alanında çalışan bilim insanı imajlarının araştırmaya katılan öğretmen adaylarının cinsiyetlerine göre istatistiksel olarak anlamlı bir farklılık gösterip göstermediği incelenmiştir. Beş farklı anabilim dalında öğrenim gören öğretmen adaylarının kimya alanında çalışan bilim insanı imajlarının, öğretmen adaylarının cinsiyetlerine göre istatistiksel olarak anlamlı farkın olup olmadığını test etmek için yapılan bağımsız gruplar için t-testi analiz sonuçları Tablo 2 ve Tablo 3'te sunulmuştur. 
Tablo 2. Öğretmen adaylarının kimya alanında çalışan bilim insanı imajlarına yönelik DAST-C puanlarının cinsiyete göre t-testi sonuçları

\begin{tabular}{lllllll}
\hline Cinsiyet & $\mathbf{N}$ & $\bar{x}$ & $\mathbf{S}$ & Sd & t & p \\
\hline Kadın & 184 & 6.3 & 1.85 & 269 & & .470 \\
\hline Erkek & 87 & 6.18 & 1.94 & .639 \\
\hline
\end{tabular}

Tablo 3. Öğretmen adaylarının kimya alanında çalışan bilim insanı imajlarına yönelik RME-C puanlarının cinsiyete göre t-testi sonuçları

\begin{tabular}{lllllll}
\hline Cinsiyet & $\mathbf{N}$ & $\bar{x}$ & $\mathbf{S}$ & Sd & t & p \\
\hline Kadın & 184 & 8.27 & 2.15 & 269 & .190 & .850 \\
\hline Erkek & 87 & 8.22 & 2.19 & & & \\
\hline
\end{tabular}

Tablo 2 ve Tablo 3 incelendiğinde öğretmen adaylarının kimya alanında çalışan bilim insanı imajlarına yönelik DAST-C ve RME-C puanları araştırmaya katılan öğretmen adaylarının cinsiyetine göre istatistiksel olarak anlamlı bir farklılık göstermemektedir $(\mathrm{p}>.05)$.

Araştırmaya katılan öğretmen adaylarının kimya alanında çalışan bilim insanı imajlarının araştırmaya katılan öğretmen adaylarının öğrenimlerine devam ettikleri sınıf düzeylerine göre (üçüncü ve dördüncü sınıflar) istatistiksel olarak anlamlı bir farkın olup olmadığg incelenmiștir. Buradan hareketle veriler iki farklı Bilim İnsanı Çizim Kontrol Listesine göre istatistiksel olarak anlamlı farkın olup olmadığını test etmek için bağımsız gruplar için t-testi analiz sonuçları Tablo 4 ve Tablo 5 'te sunulmuştur.

Tablo 4. Öğretmen adaylarının kimya alanında çalışan bilim insanı imajlarına yönelik DAST-C puanlarının öğrenim gördükleri sınıf düzeyine göre t-testi sonuçları

\begin{tabular}{lllllll}
\hline Sinif & $\mathbf{N}$ & $\bar{x}$ & $\mathbf{S}$ & $\mathbf{S d}$ & $\mathbf{t}$ & $\mathbf{p}$ \\
\hline 3. sinif & 162 & 6.13 & 1.81 & 269 & \multirow{2}{*}{1.417} & .616 \\
\hline 4. sinif & 109 & 6.46 & 1.97 & & & \\
\hline
\end{tabular}

Tablo 5. Öğretmen adaylarının kimya alanında çalışan bilim insanı imajlarına yönelik RME-C puanlarının öğrenim gördükleri sınıf düzeyine göre t-testi sonuçları

\begin{tabular}{|c|c|c|c|c|c|c|}
\hline Sinıf & $\mathbf{N}$ & $\bar{x}$ & $\mathbf{S}$ & Sd & $\mathbf{t}$ & $\mathbf{p}$ \\
\hline 3. sinif & 162 & 8.12 & 2.19 & \multirow{2}{*}{269} & \multirow{2}{*}{1.249} & \multirow{2}{*}{.202} \\
\hline 4. sinif & 109 & 8.46 & 2.10 & & & \\
\hline
\end{tabular}

Tablo 4 ve Tablo 5 incelendiğinde araştırmaya katılan öğretmen adaylarının Bilim İnsanı Çizim Kontrol Listelerine göre ortalama puanlarının birbirine çok yakın olduğu ( $>$ >.05) ve kimya alanında çalışan bilim insanı imajlarının, araştırmaya katılan öğretmen adaylarının öğrenimlerine devam ettikleri sınıf düzeylerine göre istatistiksel olarak anlamlı farklılık göstermediği anlaşılmıştır.

Dördüncü olarak öğretmen adaylarının kimya alanında çalışan bilim insanı imajlarının öğrenim gördükleri bölümlere göre farkl1lık gösterip göstermediği incelenmiştir. Veriler İki farklı Bilim İnsanı Çizim Kontrol Listesine göre ayrı ayrı kodlanarak kimya alanında çalışan bilim insanı imajlarının öğrenim gördükleri bölümlere göre istatistiksel olarak anlamlı bir farkın olup olmadığını test etmek için uygulanan scheffe sonuçları Tablo 6, Tablo 7, Tablo 8 ve Tablo 9'da sunulmuştur. 
Tablo 6. DAST-C puanlarının öğretmen adaylarının öğrenim gördüğü bölümlere göre betimsel istatistikleri

\begin{tabular}{llll}
\hline Okuduğu Bölüm & $\mathbf{N}$ & $\overline{\boldsymbol{X}}$ & $\mathbf{S}$ \\
\hline Sosyal Bilgiler Öğretmenliği & 61 & 5.2 & 1.78 \\
\hline Psikolojik Danışmanlık ve Rehberlik Öğretmenliği & 53 & 5.83 & 1.90 \\
\hline İlköğretim Matematik Öğretmenliği & 44 & 6.54 & 2.01 \\
\hline Fen Bilgisi Öğretmenliği & 84 & 6.83 & 1.94 \\
\hline Resim Öğretmenliği & 29 & 7.21 & 1.86 \\
\hline
\end{tabular}

Tablo 7. DAST-C puanlarının öğrencilerin öğrenim gördüğü bölümlere göre scheffe testi sonuçları

\begin{tabular}{lcccccc}
\hline $\begin{array}{c}\text { Varyansın } \\
\text { Kaynağı }\end{array}$ & $\begin{array}{c}\text { Kareler } \\
\text { Toplamı }\end{array}$ & Sd & $\begin{array}{c}\text { Kareler } \\
\text { Ortalaması }\end{array}$ & F & p & $\begin{array}{c}\text { Anlamlı } \\
\text { farklar }\end{array}$ \\
\hline Gruplararası & 135.953 & 4 & 3.988 & $11.073^{*}$ & $.000^{* *}$ & R- S, I-S, F-S, P- \\
\hline Gruplariçi & 816.445 & 266 & 148 & & \\
\hline Toplam & 952.399 & 270 & & S
\end{tabular}

*R:Resim öğretmenliği, F: Fen bilgisi ögretmenliği, İ: İlköğretim matematik öğretmenliği, S: Sosyal bilgiler öğretmenliği, P:

Psikolojik Danışmanlık ve Rehberlik Öğretmenliği

DAST-C'ye göre yapılan analiz sonuçları araştırmaya katılan öğretmen adaylarının öğrenim gördükleri bölümlere göre kimya alanında çalışan bilim insanı imajları arasında anlamlı bir fark olduğunu göstermektedir, $\mathrm{F}(4,266)=11.073, \mathrm{p}<.01$. Gruplar aras1 farkın hangi bölümler arasında olduğunu bulmak amacıyla yapılan Scheffe testinin sonuçlarına göre resim öğretmenliği, ilköğretim matematik öğretmenliği ve fen bilgisi öğretmenliği bölümü öğrencileri ile sosyal bilgiler öğretmenliği bölümü öğrencilerinin kimya alanında çalışan bilim insanı imajının istatistiksel olarak anlamlı bir farkın olduğu sonucuna ulaşılmıştır.

Tablo 8. RME-C puanlarının öğretmen adaylarının öğrenim gördüğü bölümlere göre betimsel istatistikleri

\begin{tabular}{llll}
\hline Okuduğu Bölüm & $\mathbf{N}$ & $\bar{x}$ & $\mathbf{S}$ \\
\hline Sosyal Bilgiler Öğretmenliği & 61 & 6.93 & 2,53 \\
\hline Psikolojik Danışmanlık ve Rehberlik Öğretmenliği & 53 & 7.87 & 2,03 \\
\hline İlköğretim Matematik Öğretmenliği & 44 & 8.48 & 2.36 \\
\hline Fen Bilgisi Öğretmenliği & 84 & 9.06 & 2.34 \\
\hline Resim Öğretmenliği & 29 & 9.07 & 1.96 \\
\hline
\end{tabular}

Tablo 9. RME-C puanlarının öğretmen adaylarının öğrenim gördüğü bölümlere göre scheffe testi sonuçları

\begin{tabular}{|c|c|c|c|c|c|c|}
\hline $\begin{array}{l}\text { Varyansın } \\
\text { Kaynağı }\end{array}$ & $\begin{array}{l}\text { Kareler } \\
\text { Toplamı }\end{array}$ & Sd & $\begin{array}{c}\text { Kareler } \\
\text { Ortalaması }\end{array}$ & $\mathbf{F}$ & $\mathbf{p}$ & $\begin{array}{l}\text { Anlamlı } \\
\text { farklar }\end{array}$ \\
\hline Gruplararası & 190.077 & 4 & 47.519 & \multirow{3}{*}{$\begin{array}{l}11.842^{*} \\
\mathrm{~S}\end{array}$} & \multirow{3}{*}{$.000^{* *}$} & \multirow{3}{*}{ R- S, İ-S, F-S, P- } \\
\hline Gruplariçi & 1067.355 & 266 & 4.013 & & & \\
\hline Toplam & 1257.432 & 270 & & & & \\
\hline
\end{tabular}

*R:Resim öğretmenliği, F: Fen bilgisi öğretmenliği, İ: İlköğretim matematik öğretmenliği, S: Sosyal bilgiler öğretmenliği, P: Psikolojik Danışmanlık ve Rehberlik Öğretmenliği

RME-C'ye göre yapılan analiz sonuçları araştırmaya katılan öğretmen adaylarının okudukları bölümlere göre kimya alanında çalışan bilim insanı imajları arasında istatistiksel olarak anlamlı bir 
farkın olduğunu göstermektedir, $\mathrm{F}(4,266)=11.842, \mathrm{p}<.01$. Gruplar arası farkın hangi bölümler arasında olduğunu bulmak amacıyla yapılan Scheffe testinin sonuçlarına göre resim öğretmenliği, ilköğretim matematik öğretmenliği ve fen bilgisi öğretmenliği bölümü öğrencileri ile sosyal bilgiler öğretmenliği bölümü öğrencilerinin kimya alanında çalışan bilim insanı imajının istatistiksel olarak anlamlı farkın olduğu sonucuna ulaşılmıştır.

Araştırmaya katılan ğretmen adaylarının öğrenim gördükleri bölümlere göre, kimya alanında çalışan bilim insanına yönelik imajlarının DAST-C göstergeleri Tablo 10'da verilmiştir.

Tablo 10. Öğretmen adaylarının kimya alanında çalışan bilim insanına yönelik imajlarının DAST-C'ye göre göstergeleri

\begin{tabular}{|c|c|c|c|c|c|c|}
\hline \multirow{2}{*}{$\begin{array}{l}\text { Göster } \\
\text { geler }\end{array}$} & \multicolumn{5}{|c|}{ Bölümler* } & \multirow[b]{2}{*}{$\begin{array}{l}\text { Topla } \\
\mathrm{m} \\
\mathrm{f}(\%)\end{array}$} \\
\hline & $\begin{array}{l}\text { S } \\
f(\%)\end{array}$ & $\begin{array}{l}\mathrm{P} \\
\mathrm{f}(\%)\end{array}$ & $\begin{array}{l}\mathrm{M} \\
\mathrm{f}(\%)\end{array}$ & $\begin{array}{l}\mathrm{F} \\
\mathrm{f}(\%)\end{array}$ & $\begin{array}{l}\mathrm{R} \\
\mathrm{f}(\%)\end{array}$ & \\
\hline Laborat & $17(27$ & $18(33$ & $26(59$ & $45(53$ & $20(68$ & $126(4$ \\
\hline $\begin{array}{l}\text { uvar } \\
\text { Önlüğü }\end{array}$ & $.87)$ & $.96)$ & $.09)$ & $.57)$ & $.96)$ & $6.49)$ \\
\hline Gözlük & $\begin{array}{l}24(39 \\
.34) \\
\end{array}$ & $\begin{array}{l}23(43 \\
.4) \\
\end{array}$ & $\begin{array}{l}16(36 \\
.36)\end{array}$ & $\begin{array}{l}43(51 \\
.19) \\
\end{array}$ & $\begin{array}{l}19(65 \\
.52) \\
\end{array}$ & $\begin{array}{l}125(4 \\
6.13) \\
\end{array}$ \\
\hline $\begin{array}{l}\text { Dağını } \\
\text { k Saç }\end{array}$ & $\begin{array}{l}50(81 \\
.97)\end{array}$ & $\begin{array}{l}23(43 \\
.4)\end{array}$ & $\begin{array}{l}42(95 \\
.45)\end{array}$ & $\begin{array}{l}79(94 \\
.05)\end{array}$ & $\begin{array}{l}19(65 \\
.52)\end{array}$ & $\begin{array}{l}213(7 \\
8.6)\end{array}$ \\
\hline $\begin{array}{l}\text { Araştır } \\
\text { ma } \\
\text { Sembol } \\
\text { leri }\end{array}$ & $\begin{array}{l}40(65 \\
.57)\end{array}$ & $\begin{array}{l}50(94 \\
.34)\end{array}$ & $\begin{array}{l}40(90 \\
.91)\end{array}$ & $\begin{array}{l}67(79 \\
.769\end{array}$ & $\begin{array}{l}28(96 \\
.55)\end{array}$ & $\begin{array}{l}225(8 \\
3.03)\end{array}$ \\
\hline $\begin{array}{l}\text { Bilgi } \\
\text { Sembol } \\
\text { leri }\end{array}$ & $\begin{array}{l}14(22 \\
.95)\end{array}$ & $\begin{array}{l}21(39 \\
.62)\end{array}$ & $\begin{array}{l}19(43 \\
.18)\end{array}$ & $\begin{array}{l}28(43 \\
.75)\end{array}$ & $\begin{array}{l}16(55 \\
.17)\end{array}$ & $\begin{array}{l}98(36 . \\
16)\end{array}$ \\
\hline $\begin{array}{l}\text { Teknol } \\
\text { oji }\end{array}$ & $\begin{array}{l}1(1.6 \\
4)\end{array}$ & $\begin{array}{l}5(9.4 \\
3)\end{array}$ & $\begin{array}{l}8(18 . \\
18)\end{array}$ & $\begin{array}{l}8(9.5 \\
2)\end{array}$ & $\begin{array}{l}7(24 . \\
14)\end{array}$ & $\begin{array}{l}29(10 . \\
7)\end{array}$ \\
\hline $\begin{array}{l}\text { Metin } \\
\text { ve } \\
\text { İfadeler }\end{array}$ & $\begin{array}{l}8(13 . \\
11)\end{array}$ & $\begin{array}{l}17(32 \\
.08)\end{array}$ & $\begin{array}{l}7(15 . \\
91)\end{array}$ & $\begin{array}{l}15(17 \\
.86)\end{array}$ & $\begin{array}{l}5(17 . \\
24)\end{array}$ & $\begin{array}{l}52 \\
(19.19 \\
)\end{array}$ \\
\hline Erkek & $\begin{array}{l}42(68 \\
.85)\end{array}$ & $\begin{array}{l}35(66 \\
.04)\end{array}$ & $\begin{array}{l}26(59 \\
.09)\end{array}$ & $\begin{array}{l}57(67 \\
.86)\end{array}$ & $\begin{array}{l}22(75 \\
.86)\end{array}$ & $\begin{array}{l}182(6 \\
7.16)\end{array}$ \\
\hline $\begin{array}{l}\text { Köken- } \\
\text { Beyaz }\end{array}$ & $\begin{array}{l}61(10 \\
0)\end{array}$ & $\begin{array}{l}52(98 \\
.11)\end{array}$ & $\begin{array}{l}44(10 \\
0)\end{array}$ & $\begin{array}{l}81(96 \\
.43)\end{array}$ & $\begin{array}{l}27(93 \\
, 1)\end{array}$ & $\begin{array}{l}265(9 \\
7.79)\end{array}$ \\
\hline $\begin{array}{l}\text { Tehlike } \\
\text { İşaretle } \\
\text { ri }\end{array}$ & $0(0)$ & $\begin{array}{l}1(1.8 \\
9)\end{array}$ & $0(0)$ & $\begin{array}{l}1(1.1 \\
9)\end{array}$ & $\begin{array}{l}1(3.4 \\
5)\end{array}$ & $\begin{array}{l}3(1.11 \\
)\end{array}$ \\
\hline $\begin{array}{l}\text { Düşünc } \\
\mathrm{e} \\
\text { Bulutu }\end{array}$ & $\begin{array}{l}2(3.2 \\
8)\end{array}$ & $\begin{array}{l}3(5.6 \\
6)\end{array}$ & $\begin{array}{l}2(4.5 \\
4)\end{array}$ & $\begin{array}{l}8(9.5 \\
2)\end{array}$ & $\begin{array}{l}3(10, \\
35)\end{array}$ & $\begin{array}{l}18(6.6 \\
4)\end{array}$ \\
\hline $\begin{array}{l}\text { Bilindi } \\
\text { k Bilim } \\
\text { İnsanı }\end{array}$ & $\begin{array}{l}1(1.6 \\
4)\end{array}$ & $\begin{array}{l}2(3.7 \\
7)\end{array}$ & $\begin{array}{l}2(4.5 \\
4)\end{array}$ & $\begin{array}{l}3(3,5 \\
7)\end{array}$ & $\begin{array}{l}2(6.9 \\
)\end{array}$ & $\begin{array}{l}10(3.6 \\
9)\end{array}$ \\
\hline $\begin{array}{l}\text { Gizlilik } \\
\text { Belirtil } \\
\text { eri }\end{array}$ & $0(0)$ & $0(0)$ & $0(0)$ & $\begin{array}{l}1(1.1 \\
9)\end{array}$ & $\begin{array}{l}1(3.4 \\
5)\end{array}$ & $\begin{array}{l}2(0.74 \\
)\end{array}$ \\
\hline
\end{tabular}




\begin{tabular}{lllllll}
\hline Araştır & $43(70$ & $43(81$ & $41(93$ & $76(90$ & $28(96$ & $231(8$ \\
ma & $.5)$ & $.13)$ & $.18)$ & $.48)$ & $.55)$ & $5.24)$ \\
Yeri & & & & & & \\
(Kapalı & & & & & & \\
Ortam) & & & & & \\
\hline Yaşl1 & $14(22$ & $16(30$ & $15(34$ & $62(73$ & $11(37$ & $118(4$ \\
veya & $.95)$ & $.19)$ & $.09)$ & $.81)$ & $.93)$ & $3,54)$ \\
Orta & & & & & & \\
yaşl1 & & & & & & \\
\hline
\end{tabular}

*R:Resim öğretmenliği, F: Fen bilgisi öğretmenliği, İ: İlköğretim matematik öğretmenliği, S: Sosyal bilgiler öğretmenliği, P: Psikolojik Danışmanlık ve Rehberlik Öğretmenliği

Tablo 10 incelendiğinde öğretmen adaylarının kimya alanında çalışan bilim insanı çizimlerinde, DAST-C göstergelerine göre sırasıyla dağınık saçlı, araştırma ve bilgi sembollerinin olduğu, erkek, beyaz kökenli ve kapalı ortamlarda çalışan algılarına rastlanılmıştır. Öğretmen adaylarının çizimlerinden örnekler Şekil 1 ve Şekil 2'de sunulmuştur.

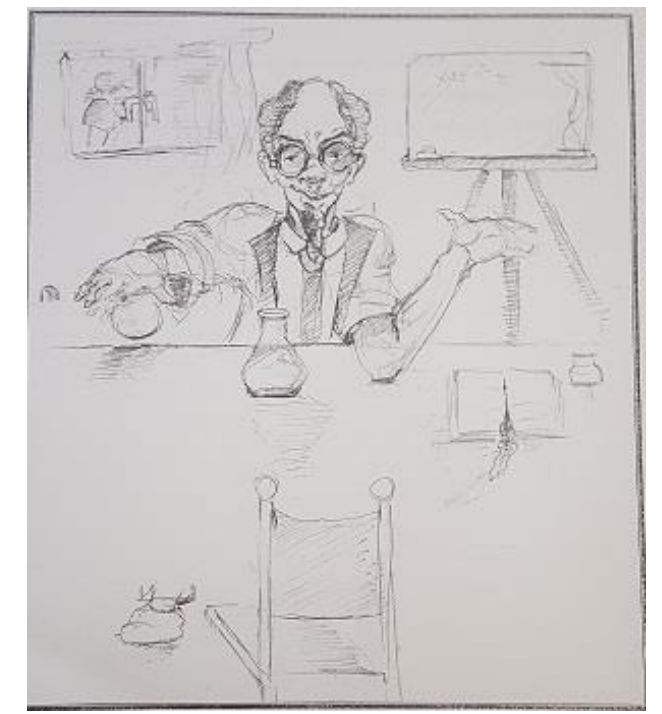

Şekil 1. Resim Öğretmenliği 4. Sınıf

Öğrencisine Ait Çizim (Kapalı ortamda çalışan)

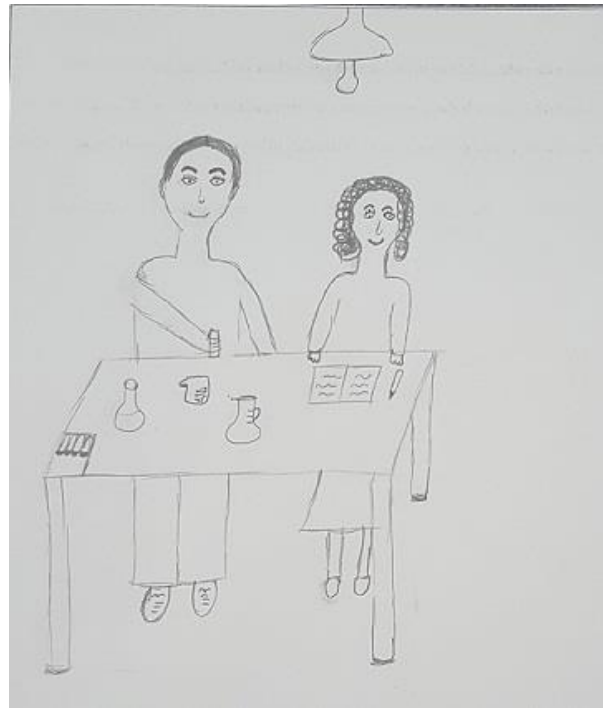

Şekil 2. PDR Öğretmenliği 3. Sınıf

Öğrencisine Ait Çizim (Beyaz kökenli)

Öğretmen adaylarının öğrenim gördükleri bölümlere göre, kimya alanında çalışan bilim insanına yönelik imajlarının RME-C göstergeleri Tablo 11'de verilmiştir.

Tablo 11. Öğretmen adaylarının kimya alanında çalışan bilim insanına yönelik imajlarının RME-C'ye göre göstergeleri

\begin{tabular}{|c|c|c|c|c|c|c|}
\hline \multirow{2}{*}{$\begin{array}{l}\text { Göstergel } \\
\text { er }\end{array}$} & \multicolumn{5}{|c|}{ Bölümler } & \multirow[b]{2}{*}{$\begin{array}{l}\text { Topla } \\
\mathrm{m} \\
\mathrm{f}(\%)\end{array}$} \\
\hline & $\begin{array}{l}\mathrm{S} \\
\mathrm{f}(\%)\end{array}$ & $\begin{array}{l}\mathrm{P} \\
\mathrm{f}(\%)\end{array}$ & $\begin{array}{l}M \\
\mathrm{f}(\%)\end{array}$ & $\begin{array}{l}F \\
f(\%)\end{array}$ & $\begin{array}{l}\mathrm{R} \\
\mathrm{f}(\%)\end{array}$ & \\
\hline Erkek & $\begin{array}{l}42(6 \\
8.85)\end{array}$ & $\begin{array}{l}35(6 \\
6.04)\end{array}$ & $\begin{array}{l}26(5 \\
9.09)\end{array}$ & $\begin{array}{l}57(6 \\
7.86)\end{array}$ & $\begin{array}{l}22(7 \\
5.86)\end{array}$ & $\begin{array}{l}12 \\
(67.1 \\
6)\end{array}$ \\
\hline $\begin{array}{l}\text { Yaşlı } \\
\text { veya Orta } \\
\text { yaşlı }\end{array}$ & $\begin{array}{l}14(2 \\
2.95)\end{array}$ & $\begin{array}{l}16(3 \\
0.19)\end{array}$ & $\begin{array}{l}15(3 \\
4.09)\end{array}$ & $\begin{array}{l}62(7 \\
3.81)\end{array}$ & $\begin{array}{l}11(3 \\
7.93)\end{array}$ & $\begin{array}{l}118(4 \\
3,54)\end{array}$ \\
\hline
\end{tabular}




\begin{tabular}{|c|c|c|c|c|c|c|}
\hline $\begin{array}{l}\text { Laboratua } \\
\text { r Önlüğ̈̈ }\end{array}$ & $\begin{array}{l}17(2 \\
7.87)\end{array}$ & $\begin{array}{l}18(3 \\
3.96)\end{array}$ & $\begin{array}{l}26(5 \\
9.09)\end{array}$ & $\begin{array}{l}45(5 \\
3.57)\end{array}$ & $\begin{array}{l}20(6 \\
8.96)\end{array}$ & $\begin{array}{l}126(4 \\
6.49)\end{array}$ \\
\hline Gözlük & $\begin{array}{l}24(3 \\
9.34)\end{array}$ & $\begin{array}{l}23(4 \\
3.4)\end{array}$ & $\begin{array}{l}16(3 \\
6.36)\end{array}$ & $\begin{array}{l}43(5 \\
1.19)\end{array}$ & $\begin{array}{l}19(6 \\
5.52)\end{array}$ & $\begin{array}{l}125(4 \\
6.13)\end{array}$ \\
\hline $\begin{array}{l}\text { Dağınık } \\
\text { Saç }\end{array}$ & $\begin{array}{l}50(8 \\
1.97)\end{array}$ & $\begin{array}{l}23(4 \\
3.4)\end{array}$ & $\begin{array}{l}42(9 \\
5.45)\end{array}$ & $\begin{array}{l}79(9 \\
4.05)\end{array}$ & $\begin{array}{l}19(6 \\
5.52)\end{array}$ & $\begin{array}{l}213(7 \\
8.6)\end{array}$ \\
\hline $\begin{array}{l}\text { Bilindik } \\
\text { Bilim } \\
\text { İnsanı }\end{array}$ & $\begin{array}{l}1(1.6 \\
4)\end{array}$ & $\begin{array}{l}2(3.7 \\
7)\end{array}$ & $\begin{array}{l}2(4.5 \\
4)\end{array}$ & $\begin{array}{l}3(3,5 \\
7)\end{array}$ & $\begin{array}{l}2(6.9 \\
)\end{array}$ & $\begin{array}{l}10(3 . \\
69)\end{array}$ \\
\hline $\begin{array}{l}\text { Ciddi } \\
\text { veya Asık } \\
\text { Suratlı }\end{array}$ & $\begin{array}{l}41(6 \\
7.21)\end{array}$ & $\begin{array}{l}28(6 \\
3.63)\end{array}$ & $\begin{array}{l}20(4 \\
5.45)\end{array}$ & $\begin{array}{l}68(8 \\
0.95)\end{array}$ & $\begin{array}{l}24(8 \\
2.76)\end{array}$ & $\begin{array}{l}181(6 \\
6.79)\end{array}$ \\
\hline $\begin{array}{l}\text { Yalnız } \\
\text { Çalışan }\end{array}$ & $\begin{array}{l}58(9 \\
5.08)\end{array}$ & $\begin{array}{l}52(9 \\
8.11)\end{array}$ & $\begin{array}{l}43(8 \\
1.13)\end{array}$ & $\begin{array}{l}80(9 \\
5.24)\end{array}$ & $\begin{array}{l}23(7 \\
9.31)\end{array}$ & $\begin{array}{l}256(9 \\
4.46)\end{array}$ \\
\hline $\begin{array}{l}\text { Araştırma } \\
\text { Disiplini: } \\
\text { Kimya }\end{array}$ & $\begin{array}{l}61(1 \\
00)\end{array}$ & $\begin{array}{l}53(1 \\
00)\end{array}$ & $\begin{array}{l}44(1 \\
00)\end{array}$ & $\begin{array}{l}84(1 \\
00)\end{array}$ & $\begin{array}{l}29(1 \\
00)\end{array}$ & $\begin{array}{l}271(1 \\
00)\end{array}$ \\
\hline $\begin{array}{l}\text { Metin ve } \\
\text { İfadeler }\end{array}$ & $\begin{array}{l}8(13 . \\
11)\end{array}$ & $\begin{array}{l}17(3 \\
2.08)\end{array}$ & $\begin{array}{l}7(15 . \\
91)\end{array}$ & $\begin{array}{l}15(1 \\
7.86)\end{array}$ & $\begin{array}{l}5(17 . \\
24)\end{array}$ & $\begin{array}{l}5(19 . \\
19)\end{array}$ \\
\hline $\begin{array}{l}\text { Araştırma } \\
\text { Semboller } \\
\text { i }\end{array}$ & $\begin{array}{l}40(6 \\
5.57)\end{array}$ & $\begin{array}{l}50(9 \\
4.34)\end{array}$ & $\begin{array}{l}40(9 \\
0.91)\end{array}$ & $\begin{array}{l}67(7 \\
9.769\end{array}$ & $\begin{array}{l}28(9 \\
6.55)\end{array}$ & $\begin{array}{l}225(8 \\
3.03)\end{array}$ \\
\hline Teknoloji & $\begin{array}{l}1(1.6 \\
4)\end{array}$ & $\begin{array}{l}5(9.4 \\
3)\end{array}$ & $\begin{array}{l}8(18 . \\
18)\end{array}$ & $\begin{array}{l}8(9.5 \\
2)\end{array}$ & $\begin{array}{l}7(24 . \\
14)\end{array}$ & $\begin{array}{l}29(10 \\
.7)\end{array}$ \\
\hline $\begin{array}{l}\text { Araştırma } \\
\text { Yeri } \\
\text { (Kapalı } \\
\text { Ortam) }\end{array}$ & $\begin{array}{l}43(7 \\
0.5)\end{array}$ & $\begin{array}{l}43(8 \\
1.13)\end{array}$ & $\begin{array}{l}41(9 \\
3.18)\end{array}$ & $\begin{array}{l}76(9 \\
0.48)\end{array}$ & $\begin{array}{l}28(9 \\
6.55)\end{array}$ & $\begin{array}{l}231(8 \\
5.24)\end{array}$ \\
\hline $\begin{array}{l}\text { Deney } \\
\text { yapıyor } \\
\text { veya } \\
\text { Düşünüyo } \\
\text { r }\end{array}$ & $\begin{array}{l}42(6 \\
8.85)\end{array}$ & $\begin{array}{l}52(9 \\
8.11)\end{array}$ & $\begin{array}{l}43(9 \\
7.72)\end{array}$ & $\begin{array}{l}74(8 \\
8.09)\end{array}$ & $\begin{array}{l}28(9 \\
6.55)\end{array}$ & $\begin{array}{l}239(8 \\
8.19)\end{array}$ \\
\hline
\end{tabular}

Tablo 11 incelendiğinde öğretmen adaylarının kimya alanında çalışan bilim insanı çizimlerinde, RME-C göstergelerine göre sırasıyla erkek, dağınık saçlı, ciddi veya asık suratlı, yalnız çalışan, araştırma sembollerinin olduğu, kapalı ortamda araştırma yapan, deney yapan veya düşünen algılarına rastlanılmıştır. Öğretmen adaylarının çizimlerinden örnekler Şekil 3 ve Şekil 4'te sunulmuştur. 


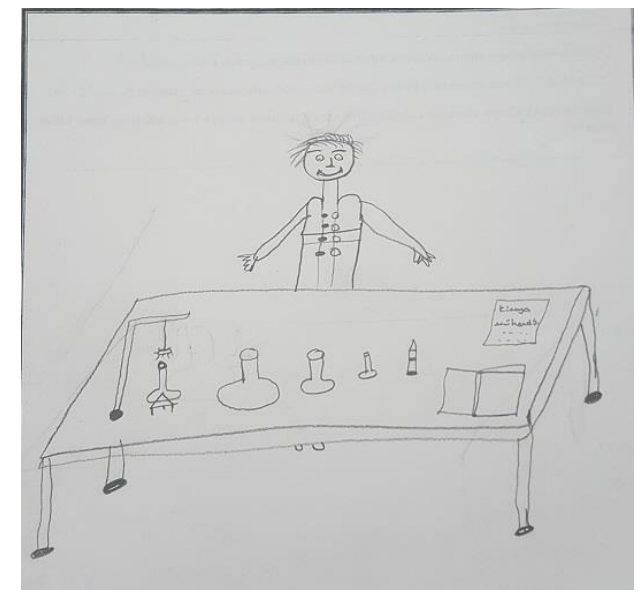

Şekil 3. Sosyal Bilgiler Öğretmenliği

3. Sınıf Öğrencisine Ait Çizim (Erkek)

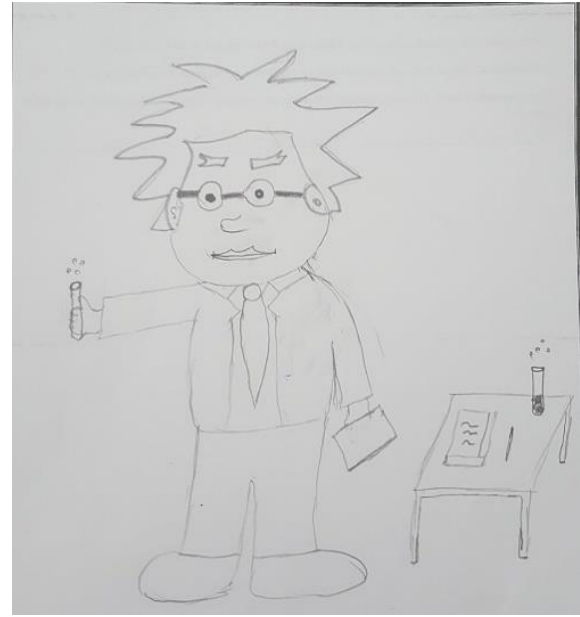

Şekil 4. Fen Bilimleri Öğretmenliği 4. Sınıf Öğrencisine Ait Çizim (Dağınık saçlı)

Öğretmen adaylarının çizimleri incelendiğinde \%3.69 oranında bilindik bilim insanı çizdikleri görülmüştür. Bu bilindik bilim insanları Einstain, Kohler gibi bilim insanları oldukları gibi bazı dizilerde yer alan karakterlerin olduğu da bulunmuştur. Şekil 5, Şekil 6 ve Şekil 7'de bilindik bilim insanlarına dair öğretmen adaylarının çiziml1 erinden örnekler sunulmuştur.

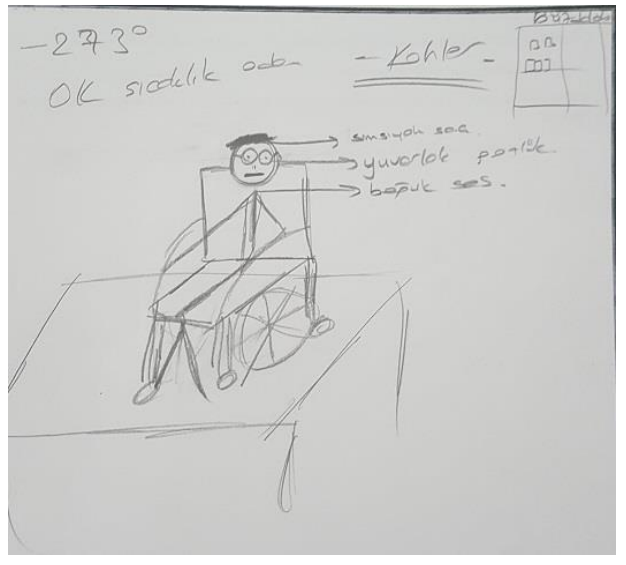

Şekil 5. İ.M.Ö 3. sınıf öğrencisine ait Kohler çizimi

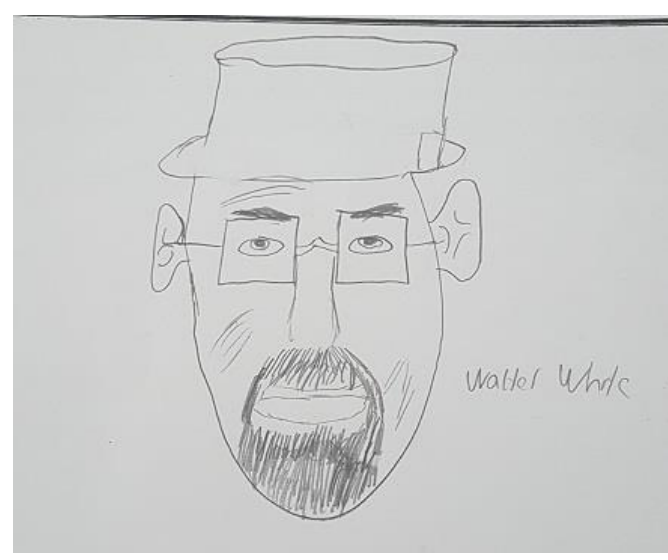

Şekil 6. İ.M.Ö 3. sınıf öğrencisine ait dizi kahramanı çizimi

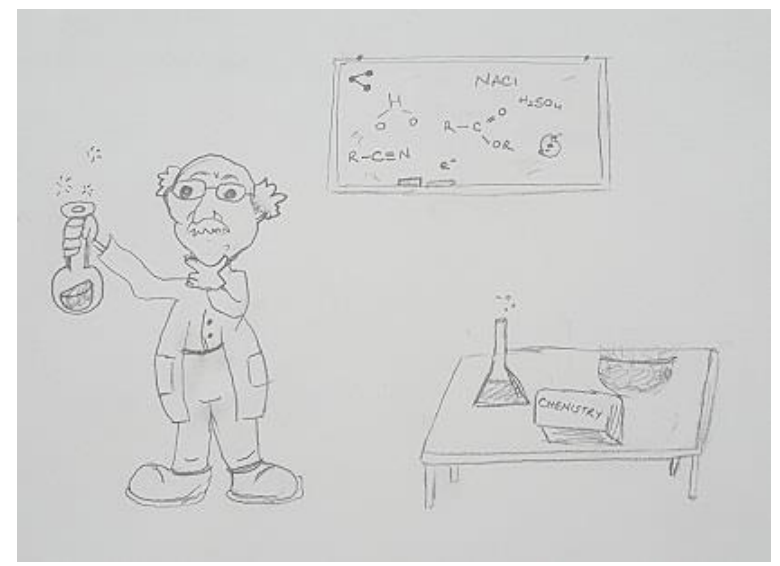

Şekil 7. PDR Öğretmenliği 4. sınıf öğrencisine ait Einstain çizimi 


\section{TARTIŞMA, SONUÇ ve ÖNERILER}

Araştırmaya katılına eğitim fakültesinin beş farklı anabilim dalında öğrenim gören öğretmen adaylarının kimya alanında çalışan bilim insanı imajları ve bu imajlara etki eden faktörler incelenmiştir. Öğretmen adaylarının iki farklı Bilim İnsanı Çizim Kontrol Listesi puanları incelendiğinde, kimya alanında çalışan bilim insanı imajlarının geleneksel bilim insanı imajı olduğu bulunmuştur. İki farklı Bilim İnsanı Çizim Kontrol Listesindeki maddeler tek tek incelendiğinde bu durum daha iyi anlaşılmaktadır. Öğretmen adaylarının imajlarının, geleneksel bilim insanı ile örtüșen özellikleri cinsiyet, çalışma ortamı, dağınık saç ve sakal, ırk iken, örtüşmeyen özellikleri yaş ve gözlük olmuştur. Kimya alanında çalışan bilim insanı imajına cinsiyet açısından bakıldığında bu oranın \%67,16 ile erkek olduğunu görülmüştür. Katılımcıların büyük bir kısmının kadın olmasına $(\% 67,9)$ rağmen sonuçlar diğer yapılan çalışmalar ile benzer sonuçlar vermiştir (Chambers, 1983; Korkmaz ve Kavak, 2010; Özkan vd., 2017).

Araştırma sonucunda kimya alanında çalışan bilim insanı imajlarının \%78,6 oranında dağınık saçlı olduğu sonucuna ulaşılmıştır. Bu sonuçlar yapılan diğer araştırmalar ile örtüşmektedir (Korkmaz ve Kavak, 2010; Özsoy ve Ahi, 2014; Eyceyurt-Türk ve Tüzün, 2017;) araştırmalarıyla örtüşmektedir. Öğretmen adaylarının kimya alanında çalışan bilim insanı imajlarını geleneksel bilim insanı imajından ayrılan yönler; bu çalışmada çizimlerinin genç olması ve bu çizimlerde gözlük kullanılmamasıdır. Bunun nedeni çevrelerinde ve öğrenim gördükleri eğitim kurumlarında yer alan bilim insanlarının yaşlarının genç ve gözlük kullanmıyor olmaları olabilir.

Araştırmada kimya alanında çalışan bilim insanı imajlarında çalışma ortamlarının \%85,24 ile kapalı ortam olduğu bulunmuştur. Bu sonuç, birçok araştırma sonucu ile tutarlık göstermektedir (Mead ve Metraux, 1957; Ağgül-Yalçın, 2012; Turgut, Öztürk, ve Eş, 2017). Bunun nedeni kimya derslerinin ya sınıf ya da laboratuvar gibi kapalı ortamlarda işlenmesi olabilir.

Öğretmen adaylarının kimya alanında çalışan bilim insanı imajlarının DAST-C ve RME-C puanları arasında cinsiyete ve öğrenim düzeylerine göre istatistiksel olarak anlamlı bir fark görülmemiştir. DAST-C ve RME-C puanları arasında, öğrenim görülen bölümlere göre farka bakıldığında istatistiksel olarak sosyal bilgiler öğretmenliği bölümü öğrencilerinin test puanlarının, diğer dört farklı öğretmenlik bölümlerinden anlamlı olarak farklılaştı̆̆ı bulunmuştur. DAST-C ve RME$\mathrm{C}$ maddelerine göre çizimler incelendiğinde sosyal bilgiler öğretmenliği bölümü öğrencilerinin kimya alanında çalışan bilim insanına yönelik imajlarının geleneksel bilim insanı imajından az da olsa uzaklaştığı saptanmıştır (bilim insanının yaşı, önlük, gözlük gibi). Literatürde üniversite öğrencilerinin bilim insanı imajları üzerine öğrenim gördükleri bölümlerin etkisi üzerine çok az sayıda çalışma vardır. $\mathrm{Bu}$ araştırmada sosyal bölümler içerisine giren sosyal bilgiler öğretmenliğinin istatistiksel olarak diğer bölümlerden kimya alanında çalışan bilim insanı imajları anlamlı düzeyde farklılık gösterse de yapılan diğer çalışmalarda sayısal ve sözel bölümü öğrencilerinin bilim insanı imajlarının farklı olmadığı sonucu ortaya konulmuştur (Özkan vd., 2017).

Araştırmada son olarak İki farklı Bilim İnsanı Çizim Kontrol Listesinde yer almayan ancak bu çizimlerin olduğu çalışma yaprağında yer alan açık uçlu soruya yazılan ifadelerden edilen veriler doğrultusunda öğretmen adaylarının zihinlerinde yer alan kimya alanında çalışan bilim insanı imajlarına yönelik bazı bulgulara ulaşılmıştır. Araştırmaya katılan öğretmen adaylarının çizimlerinde bilinen bilim insanlarından, Einstein, Kohler ve bir dizi kahramanı olan Walter White gibi bazı bilim insanları görülmüştür. Araştırmaya katılan öğretmen adaylarının bu karakterleri çizmeleri bilim insanı imajı üzerinde medya araçlarından, internet, televizyon gibi araçların etkili olduğu sonucuna ulaşıla bilinir. Buradan araştırmaya öğretmen adaylarının, film, internet, kitaplar ve gazete gibi medya organlarına dayalı olarak bilim insanı imajı geliştirdikleri anlaşılmışıı (Kibar-Kavak, 2008; Kara, 2013; Karaçam vd., 2014). Bu bulgu Ten-Eyck (2005)'in medyanın insanların düşüncelerine etkileri üzerine araştırma bulguları ile de örtüşmektedir.

Ayrıca araştırma önerisi olarak; daha geniş bir örneklem grubu ile birebir görüşmeler yapılarak daha kapsamlı çalışmalar yürütülebilir. Çalışmada öğretmen adaylarının zihinlerindeki kimya alanında çalışan bilim insanı imajlarının yüksek oranda (\% 67.16) erkek olduğu bulgusuna ulaşılmıştır. Bizler eğitimciler olarak öğrencilerimizde doğru bir biçimde bilimin doğası algısı oluşturmak istiyorsak bu işe öncelikle bilimsel olarak doğru bilimin doğası algısı edinmiş öğretmen adayları yetiştirerek başlamalıyız ki bunun da yolu kuşkusuz eğitim fakültelerinden geçmektedir. Öğretmen adaylarımızda 
ne kadar düzgün bir biçimde bilimin doğası algısı parmak izi oluşturabilirsek öğrencilerine de benzer yaşanmışlıklar sunabilecek olmaları muhtemeldir. Destekleyici önlemler olarak eğitim-öğretim süresince görsel ve işitsel medya aracılığıyla sadece erkek bilim insanlarının olmadığı, kadınların da bilim insanı olabileceği vurgusu yapılabilir. Ayrıca kaynak kitaplarında kadın bilim insanlarına da yer verilerek, bilim insanın sadece erkek olabileceğine yönelik imajlar değiştirilebilir. Bunu yanında bilim insanı imajı ve bilimin doğasına yönelik etkinlikler ile de hem öğretmen adaylarının hem de öğrencilerin imajları bilimsel olarak daha doğru olarak yapılandırılabilir. Öğrencilerin bir diğer bilim insanı imajı oluşturma kaynağ 1 ise fen ders kitaplarıdır ve bu kitaplardaki sunulan imajlar geleneksel bilim insanı imajı ile örtüşmektedir (Karaçam vd., 2014). Bu bağlamda ders kitaplarında kullanılan görseller, bilim insanı imajlarını doğru yapılandıracak șekilde düzenlenmeli ve revize edilmelidir. Farklı branşlarda kimya da dâhil - çalışan kadın-erkek bilim insanlarıyla örnekler zenginleştirilerek bilim insanı imajı doğru olarak oluşturulabilir.

\section{KAYNAKÇA}

Acisli S. \& Kumandas H. (2019). Middle school students' images of scientists after a Project called "Artvin natüre and science camp". Europen Journal of Education Studies. 6(6), 200-207.

Ağgül Yalçın, F. (2012). Öğretmen adaylarının bilim insanı imajlarının bazı değişkenlere göre incelenmesi. Ilköğretim Online, 11(3), 611-628.

Akçay, B. (2011). Turkish elementary and secondary students' views about science and scientist. AsiaPacific Forum on Science Learning and Teaching, 12(1), 1-11

Aslan, O., Yalçın, N. \& Taşar, F. (2009). Fen ve teknoloji öğretmenlerinin bilimin doğası hakkındaki görüşleri. Ahi Evran Üniversitesi Eğitim Fakültesi Dergisi, 10(3), 1 - 8.

Aydın, A. (2016). Kimyaya genel bakış, (genel kimya 1 kitabında bölüm, editör: Canan Nakiboğlu), 1. Bask1, Ankara: Anı Yayınc1lık, ISBN:978-605-170-125-7.

Bodzin, A. \& Gehringer, M. (2001). Breaking science stereotypes. Science \& Children, 38(4), 36-41.

Camcı-Erdoğan, S. (2018). Üstün zekâlılar öğretmenliği adaylarının gözlerinden bilim insanları. YYÜ Eğitim Fakültesi Dergisi (YYU Journal of Education Faculty), 15(1), 130-155,

Chambers, D. W. (1983). Stereotypic images of the scientist: the draw- a scientist test. Science Education, 67(2), 255-265.

Creswell, J. W. (2017). Karma yöntem araştırmalarına giriş. M. Sözbilir (Çev. Ed.). Pegem: Ankara.

Çermik, H. (2013). Öğretmen adaylarının zihinlerinde canlanan resimdeki bilim insanı. Pamukkale Üniversitesi Eğitim Fakültesi Dergisi, 33(1), 139-153.

Dede, Ö. (2019). Mevsimlik tarim işçisi ailelerin ortaokul ögrencilerine göre bilim insani algilarinin belirlenmesi. Yayımlanmamış yüksek lisans tezi, Ordu Üniversitesi Fen Bilimleri Enstitüsü, Ordu.

Demirbaş, M. (2009). The relationships between the scientist perception and scientific attitudes of science teacher candidates in Turkey: A case study. Scientific Research and Essay, 4(6), 565-576.

Doğan, N., Çakıroğlu, J., Bilican, K. \& Çavuş- Güngören, S. (2014). Bilimin doğası ve öğretimi. Ankara: Pegem Akademi

Eyceyurt Türk, G. \& Tüzün Ü.N. (2017). Lise öğrencilerinin bilim insanı imajları ve bilimin doğası mitleri. Ahi Evran Üniversitesi Kırşehir Ë̆itim Fakültesi Dergisi, 18(2), 19-36.

Emvalotis, A. \& Koutsianou A. (2018). Greek primary school students' images of scientists and their work: has anything changed?, Research in Science \& Technological Education, 36(1), 69-85.

Fung, Y.Y.H. (2002). A comparative study of primary and secondary school students' images of scientists. Research in Science and Technological Education, 20(2), 199-213.

Finson, K., Beaver, J. \& Cramond, B. (1995). Development and field test of a checklist for the draw-ascientist test. School Science and Mathematics, 95 (4), 195-205.

Gheith E. \& Aljaberi N. M. (2019). The image of scientists amon pre-service classroom and child education teachers in Jordan. International Journal of Instruction. 12(4). 561-578.

Gürses, A., Doğar, Ç., \& Yalçın, M. (2005). Bilimin doğası ve yüksek öğrenim öğrencilerinin bilimin doğasına dair düşünceleri Milli Eğitim Dergisi, 166, 1-5.

Jones, R. \& Bangert, A. (2006). The CSI effect: changing the face of science. Science Scope, November, $38-42$.

Kara, B. (2013). Ortaokul ögrrencilerinin bilim insanına yönelik tutum ve imajlarının belirlenmesi. Yayımlanmamış yüksek lisans tezi, Erciyes Üniversitesi Eğitim Bilimleri Enstitüsü, Kayseri. 
Karaçam, S. (2016). Scientist-image stereotypes: the relationships among their indicators. Educational Sciences: Theory \& Practice, 16(3), 1027-1049

Karaçam, S., Aydın, F. \& Digilli, A. (2014). Fen ders kitaplarında sunulan bilim insanlarının basmakalıp bilim insanı imajı açısından değerlendirilmesi. Ondokuz Mayıs Üniversitesi Ĕ̆itim Fakültesi Dergisi, 33(2), 606627

Kaya, O. N., Doğan, A. \& Öcal, E. (2008). Turkish elementary school students' images of scientists. Eurasian Journal of Educational Research, 32, 83-100.

Kibar-Kavak, G. (2008). Ögrencilerin bilime ve bilim insanına yönelik tutumlarını ve imajlarını etkileyen faktörler. Yayımlanmamış yüksek lisans tezi, Selçuk Üniversitesi Sosyal Bilimler Enstitüsü, Konya

Koren, P. \& Bar, V. (2009). Perception of the image of scientist by Israeli student teachers from two distinct communities in Israel: Arabs and Jews. Eurasia Journal of Mathematics, Science and Technology Education, 5(4), 347-356.

Korkmaz, H. \& Kavak, G. (2010). İlköğretim öğrencilerinin bilime ve bilim insanına yönelik imajları. İlkögrretim Online, 9(3), 1055-1079.

Köseoğlu, F., Tümay, H. \& Budak, E. (2008). Bilimin doğası hakkında paradigma değişimleri. Gazi Üniversitesi Gazi Ĕ̈itim Fakültesi Dergisi, 28(2), 221-237.

Köseoğlu, F., Tümay, H. \& Üstün, U. (2010). Bilimin doğası öğretimi mesleki gelişim paketinin geliştirilmesi ve öğretmen adaylarına uygulanması ile ilgili tartışmalar. Ahi Evran Üniversitesi Eğitim Fakültesi Dergisi, 129-163.

Meyer, C., Guenther, L. \& Joubert, M. (2019). The draw-a-scientist test in an african context: comparing students' (stereotypical) images of scientists across university faculties, Research in Science \& Technological Education, 37(1), 1-14.

Mbajiorgu, N. M., \& Iloputaife, E. C. (2001). Combating stereotypes of the scientist among pre-service science teachers in Nigeria. Research in Science \& Technological Education, 19(1), 55-67.

Milford, T. M. \& Tippet, C. D. (2013). Preservice teachers' images of scientists: do prior science experiences make a difference?. Journal of Science Teacher Education. 24(4). 745-762.

Öcal, E. (2007). İlköğretim 6, 7, 8. sınıf öğrencilerinin bilim insanı hakkındaki imaj ve görüşlerinin belirlenmesi. Yayımlanmamış yüksek lisans tezi, Gazi Üniversitesi Eğitim Bilimleri Enstitüsü, Ankara.

Özkan, B., Özeke, V., Güler, G. \& Şenocak, E. (2017). Üniversite öğrencilerinin bilim insanı imajları ve bu imajları etkileyen bazı faktörler. Erzincan Üniversitesi Eğitim Fakültesi Dergisi, 19(1)

Rahm, J., \& Charbonneau, P. (1997). Probing stereotypes through students' drawings of scientists. American Journal of Physics, 65(8), 774-778.

Ruiz-Mallén, I \& Escalas, M.T. (2012). Scientists seen by children: a case study in Catalonia, Spain. Science Commutation, 34(4), 520-545.

Schibeci, R.A. \& Sorenson, I. (1983). Elementary school children's perceptions of scientists, School Science and Mathematics. 83 (1): 14-19.

Scott, A. B., \& Mallinckrodt, B. (2005). Parental emotional support, science self-efficacy, and choice of science major in undergraduate women, The Career Development Quarterly, 53, 263-273.

Subramaniam, K., Harrell, P. E. \& Wojnowski, D. (2013). Analyzing prospective teachers' images of scientists using positive, negative and stereotypical images of scientists, Research in Science \& Technological Education, 31(1), 66-89.

Şenel, T. \& Aslan, O. (2014) Okul öncesi öğretmen adaylarının bilim ve bilim insanı kavramlarına ilişkin metaforik algıları. Mersin Üniversitesi Ë̆itim Fakültesi Dergisi, 10(2), 76-95.

Ten Eyck, T. A. (2005). The media and public opinion on genetics and biotechnology: mirrors, windows or walls?, Public Understanding of Science, 14, 305-316.

Tenenbaum, H. R., \& Leaper, C. (2003). Parent-child conversations about science: The socialization of gender inequities? Developmental Psychology, 39(1), 34-47.

Turgut, H., Öztürk, N. \& Eş, H. (2017). Üstün zekâlı öğrencilerin bilim ve bilim insanı algısı. Abant İzzet Baysal Üniversitesi Ĕgitim Fakültesi Dergisi, 17 (1), 423-440.

Türkmen, H. (2008). “Turkish primary students' perceptions about scientist and what factors affecting the image of the scientists", Eurasia Journal of Mathematics, Science \& Technology Education (EJMSTE), 4(1), 5561. 
Ürey, M., Karaçöp, A., Göksu, V. \& Çolak, K. (2017). Fen ve sosyal bilimler kökenli öğretmen adaylarının bilim insanı algıları. YYÜ Eğitim Fakültesi Dergisi (YYU Journal Of Education Faculty), Cilt:XIV, Sayı:I ,205226 